\section{Reporting on COVID-19 - or not? Annual report disclosure of the pandemic as a subsequent event}

Pierre Donatella

School of Public Administration, University of Gothenburg, Gothenburg, Sweden

Mattias Haraldsson

School of Economics and Management, Lund University, Lund, Sweden, and

Torbjörn Tagesson

Department of Management and Engineering, Linköping University, Campus Valla, Linköping, Sweden

\begin{abstract}
Purpose - This paper focuses on the extent to which Swedish municipalities identified and communicated risks due to the COVID-19 outbreak early on. The purpose of this paper is to explore to what extent the situational factors of the COVID-19 pandemic influenced the likelihood of municipalities disclosing COVID-19 information as a subsequent event in the annual reports of 2019.

Design/methodology/approach - Logistic regression models were used to estimate COVID-19 disclosure as a subsequent event. Data were handpicked from annual reports, audit reports and meeting minutes, or were retrieved from publicly available sources.

Findings - Regression results indicate that municipalities issuing their annual report in a later stage of the pandemic, in regions with a higher number of confirmed COVID-19 cases, were more likely to disclose COVID-19 information as a subsequent event. However, the municipal factors used to capture the risk of a severe impact of the COVID-19 outbreak were not of major importance. In line with previous research, this study shows that political and institutional factors have explanatory power in predicting and explaining accounting disclosure choices.

Originality/value - This paper contributes to research on accounting disclosures in urgent crises and on the specific topic of subsequent events in the public sector. Few studies address subsequent events in a corporate setting and, to the best of the authors' knowledge, none do so in the context of the public sector. This paper also offers insight into how explanatory factors, previously tested under normal conditions and circumstances, influence disclosure choices in an early stage of a health crisis characterized by uncertainty regarding both occurrence and consequences.
\end{abstract}

Keywords Annual report, Crisis, COVID-19, Disclosure, Public sector accounting, Subsequent event Paper type Research paper

\section{Introduction}

In hindsight, it is clear that the COVID-19 outbreak evolved rapidly during the beginning of 2020, resulting in major consequences - both financially and operationally - for many public sector organizations around the world. The first official cases of the disease had already been reported in Wuhan at the end of 2019. However, at that time, the general perception in Sweden - which is the setting of this study - was that COVID-19 would probably not affect Swedish society more or differently than the 2003 SARS outbreak in China had done. With time, it became evident that this was not the case. On February 1, 2020, the Swedish central

(C) Pierre Donatella, Mattias Haraldsson and Torbjörn Tagesson. Published by Emerald Publishing Limited. This article is published under the Creative Commons Attribution (CC BY 4.0) licence. Anyone may reproduce, distribute, translate and create derivative works of this article (for both commercial and non-commercial purposes), subject to full attribution to the original publication and authors. The full terms of this licence may be seen at http://creativecommons.org/licences/by/4.0/legalcode
Reporting on COVID-19 - or not?

Received 21 April 2021 Revised 11 August 2021 4 October 2021

Accepted 15 October 2021 
government responded to a request from the Public Health Agency of Sweden and classified COVID-19 as a disease constituting a danger to society. Approximately a month later, on March 11, 2020, the World Health Organization (WHO) declared COVID-19 to be a pandemic.

Sweden's COVID-19 strategy has been analyzed and compared with the strategies of other European countries in a number of published papers (e.g. Argento et al., 2020; Kuhlmann et al., 2021). Two conditions appear to distinguish Sweden in comparison with other countries. Aside from the fact that Sweden's legal system limited the ability of the central government to restrict citizens' right to free movement (Argento et al., 2020; Kuhlmann et al., 2021), Sweden has a highly decentralized administrative system in which local governments have a farreaching autonomy. Hence, the consequences of the pandemic largely influence the activities that lie within the responsibility of the local tier of government, rather than the central government (Granberg et al., 2021; Kuhlmann et al., 2021).

According to international accounting standards (IAS 10; IPSAS 14) and Swedish accounting laws (The Annual Accounts Act, Chapter 5, Section 22; The Municipal Bookkeeping and Accounting Act, Chapter 11, Sections 2-4), both private and public sector organizations must report subsequent events - that is, information that becomes available after the balance sheet date but before the issuance of the financial statements. Also, from an audit perspective, auditors must consider all events that occur until the auditor's report is signed (ISA 560). Indeed, shortly after the WHO statement, both individual audit firms and the institute for the (private sector) accountancy profession in Sweden clearly stated that the COVID-19 outbreak must be considered as a subsequent event that should be disclosed in the annual reports issued during the spring of 2020 (e.g. FAR, 2020; KPMG, 2020; Singh, 2020). However, these statements were directed toward private sector organizations. No equivalent statements were specifically made by audit firms regarding local governments. Neither the Swedish Association of Local Authorities and Regions (SALAR) nor the accounting standard-setting body - that is, the Swedish Council of Municipal Accounting (SCMA) made such a clarification. Hence, the question is whether Swedish local governments considered the COVID-19 outbreak to be a subsequent event of material importance at the time when the annual report for 2019 was prepared, early in 2020.

Given this background, the analysis in this paper centers on why some municipalities disclosed COVID-19 information as a subsequent event in their annual report, while others did not. Previous accounting disclosure research in Sweden (Tagesson et al., 2013; Donatella, 2020; Donatella and Tagesson, 2021) and internationally (Rodríguez Bolívar et al., 2013; Bisogno et al., 2017) has mainly focused on explaining municipal disclosure choices by means of various political, economic and institutional factors under normal conditions and circumstances, without explicitly considering the uncertainty created by the swift development of a crisis (e.g. Ahrens and Ferry, 2020). Of course, municipalities are influenced by uncertainties to different degrees under normal conditions and circumstances as well; however, as these uncertainties stem from the unpredictability of the actions of regulators, citizens and suppliers, as well as economic and technological development (Allegrini and Monteduro, 2018; Gosh and Olsen, 2009), they are different from uncertainties in a health crisis context. Crises, such as the COVID19 pandemic, are better described as low-probability events with strong impacts (Roux-Dufort, 2016), which develop in stages over time (Frandsen and Johansen, 2009). In relation to subsequent events, the event perspective is relevant to the pandemic, since there will be a different degree of uncertainty, depending on the crisis stage, regarding whether the pandemic will affect the municipality and, if so, how uncertain the consequences will be (Wolling, 2016).

Municipal financial reporting is considered to be a highly institutional practice that is influenced by forces that are both internal and external to the organizational field (Carpenter and Feroz, 2001; Oulasvirta, 2014; Jorge et al., 2021; Polzer et al., 2021). Within institutional theory, uncertainty is a central condition with respect to institutional isomorphism (Meyer and Rowan, 1977; DiMaggio and Powell, 1983) and to how organizations strategically 
respond to institutional processes (Oliver, 1991). More specifically, Oliver (1991) argues that uncertainty is a significant dimension of context that affects organizations' conformity or resistance to institutional pressure and expectations. Depending on the situation, uncertainty can either stimulate disclosures or result in reluctance to disclose information. Since Swedish municipalities were influenced differently by the development of COVID-19 during the early stages of the pandemic crisis, and since Swedish municipalities do not issue their annual reports at the same time, it can be assumed that the municipalities faced different degrees of uncertainty regarding the occurrence and consequences of the pandemic when their annual reports of 2019 were prepared. It is therefore proposed that the situational factors of the crisis (e.g. Lee and Boynton, 2017) at the time of reporting play an important role in explaining COVID-19 reporting among Swedish municipalities. More specifically, in this paper, we explore whether reporting time, regional confirmed cases, demographic factors (i.e. proportion of the senior population), operational risk factors (i.e. proportion of seniors living in nursing homes) and financial risk factors (i.e. holding shares and securities) influence the likelihood of municipalities disclosing COVID-19 information as a subsequent event in their annual reports of 2019. The argument is that these situational factors reduce the degree of uncertainty regarding occurrence and consequences while increasing the access to more validated information, and therefore make the risks clearer, more tangible, and more calculable. Thus, the purpose of this study is to explore to what extent the situational factors of the COVID-19 pandemic influenced the likelihood of municipalities disclosing COVID-19 information as a subsequent event in the annual reports of 2019.

By its very nature, a subsequent event has had - or potentially will have - a material effect on the performance of the organization. Thus, neglecting to report a subsequent event of material importance, such as the COVID-19 outbreak, could imply that the reporting is misleading (Michels, 2017). This paper contributes to the research on accounting disclosures in urgent crises and to the specific topic of subsequent events in the public sector. As recognized by Czerney et al. (2020), few studies address subsequent events in a corporate setting and, to the best of our knowledge, there are no such studies in the context of the public sector. Similarly, as stated by Ahrens and Ferry (2020), the literature on the role of accounting in urgent crises is limited. This paper also contributes to the current understanding of how explanatory factors previously tested under relatively normal conditions and circumstances - influence municipalities' disclosure choices in an early stage of a health crisis characterized by (1) uncertainty regarding whether the pandemic will materialize and (2) uncertainty regarding what the consequences will be. Finally, this paper offers insights into the reactions of Swedish municipalities during the early stage of the COVID-19 outbreak, thereby complementing previous descriptions of Sweden's approach to managing the pandemic.

\section{Municipalities, financial reporting and crises}

As stated in the introduction, there are no studies that address the public sector reporting of subsequent events during crises. Therefore, we build this section around literature on the topic of subsequent events and the characteristics of crises.

\subsection{Municipal accounting and events after the balance sheet date}

By definition, a subsequent event relates to information that becomes available after the balance sheet date but before the financial statements have been issued. As explained by Michels (2017), there are two types of subsequent event: (1) additional evidence about conditions that existed at the balance sheet date and (2) evidence about conditions that did not exist at the balance sheet date. This paper focuses on the latter category of subsequent events. This kind of subsequent event involves the disclosure of future-oriented information, which has not traditionally been a priority in public sector financial reporting. Rather, financial
Reporting on COVID-19 - or not? 
reporting is generally related to the approved budget and is a cornerstone in ex post accountability (Ellwood and Newberry, 2016; Mann et al., 2019; Oulasvirta, 2021). This approach still dominates in accounting regulation and practices in Sweden (Tagesson and Grossi, 2015). In such a conservative accounting environment, verifiable and reliable information on past events is generally preferred over future-oriented information, which is characterized by greater uncertainty.

International accounting standards require public sector organizations to evaluate information that becomes available after the balance sheet date but before the issuance of the financial statements (IPSAS 14). This regulation, which is applicable to Swedish municipalities, is harmonized in this respect and aligns with international standards. The Municipal Bookkeeping and Accounting Act states that the annual report must provide futureoriented information about so-called subsequent events, risks and uncertainties. Sections $2-4$ in Chapter 11 of the Act state that, if there have been events of material importance after the end of the financial year (i.e. subsequent events) that are not reflected in the balance sheet or income statement, then the municipality must provide information about these events. Further guidance is offered in SCMA Accounting Standard 15. Although a subsequent event may be clear-cut in some instances, Czerney et al. (2020) point out that subsequent events often involve negotiation between managers and auditors, and require professional judgment and knowledge of the conditions and circumstances. Typical examples of subsequent events after the balance sheet date include an unusually large decline in the value of property carried at fair value, an acquisition or disposal of a major controlled entity, major purchases and disposals of assets, the destruction of a major building, and commencing major litigation (IPSAS 14). According to the International Federation of Accountants (IFAC), with respect to reporting periods ending on December 31, 2019, there is a general consensus that the effects of the COVID-19 outbreak are the result of events that arose after the balance sheet date (IFAC, 2020). Thus, even if the event of COVID-19 itself was known before the balance sheet date, it is difficult for external stakeholders to analyze and understand the financial and operational consequences without further information being reported.

\subsection{Crises and disclosures in annual reports}

There are many types of crises, including those related to war and terrorism, disasters and pandemics, financial problems and politics. The impact of a crisis can vary in nature and may be global, national, local or organizational. Crises can also develop in different ways: some are immediate, giving people little time to react, while others develop at a slower pace (Avery et al., 2016).

There is no universal definition of the term "crisis"; however, from an event perspective, crises are described as low-probability events that are often associated with strong impacts (Roux-Dufort, 2016). Taking a broader approach, Frandsen and Johansen (2009) describe crises as dynamic processes with three stages: the pre-crisis, the crisis event and the postcrisis. Wolling (2016) describes the pre-crisis stage as the time before a crisis event occurs. Although this time might still be characterized as a normal, undisturbed situation, information and possible risks exist that might challenge the situation. The next stage - the event stage - is when the crisis actually occurs. In this stage, uncertainty about consequences may still prevail (Wolling, 2016). In the post-crisis stage, when the crisis is over, the consequences are known and must be managed.

Ahrens and Ferry (2020) compare the emergence of the COVID-19 pandemic to the last financial crisis. They argue that the financial crisis, which resulted in the adoption of austerity programs in many European countries (e.g. Barbera et al., 2017), came with a forewarning so local authorities could prepare. In contrast, COVID-19 was much more immediate in its impact and implications and gave local authorities little time to plan or carry out mitigation activities (Ahrens and Ferry, 2020). The literature on crisis management 
emphasizes that an early reaction to a crisis is essential in order to reduce or limit the impact of that crisis (Avery et al., 2016). For municipalities, the ability to detect a crisis early on is crucial, as municipalities are often the primary actors during a crisis. However, according to Frandsen and Johansen (2009), municipalities are firmly anchored in an emergency logic in which action is taken to control an event when it occurs - which is problematic from a crisis management perspective. In other words, the very nature of a crisis is defined by the inability of organizations to plan for it in advance (Roux-Dufort, 2016). Wolling (2016) also comments that it is useful to distinguish among the different phases of a crisis, since the characteristics of uncertainty change during a crisis. Uncertainty about the probability of a crisis occurring is replaced by uncertainty about the further development and consequences of the crisis.

Due to the high level of uncertainty in the early stages of a crisis, reporting on such subsequent events poses a challenge for municipalities. Nevertheless, reporting in these stages is important, for several reasons. The ways in which municipalities communicate their pre-crisis readiness, in line with disclosure requirements, provide stakeholders with information on the perceived present and future risks. During an early stage of a crisis, questions of accountability are not adequate. Rather, the emphasis should be placed on information about the potential risks of the situation (Roux-Dufort, 2016). In later stages of crisis development, information may also be important for accountability purposes. In addition, information in the pre-stage or early stage of a crisis serves as an indicator of the readiness of the municipality, as "early-warning" detection systems are crucial for speedy and effective responses (e.g. Bouckaert et al.,2020). In crisis situations with their associated uncertainties, stakeholders' need and demand for information increases (Lee and Boynton, 2017). Timely information may therefore satisfy stakeholders' increasing demand for information, creating trust and legitimacy (Huang and Su, 2009). The ways in which municipalities communicate about a crisis have direct implications for public wellbeing, and ultimately shape public opinion about the municipality (Avery et al., 2016). Relating more specifically to the COVID-19 pandemic, IPSASB (2020, p. 1) emphasizes:

... high-quality accrual-based financial reporting is needed now, more than ever, as it provides better information for decision-making, improves transparency on how public resources are used, allows citizens to hold decision-makers to account, and better positions governments to address the balance sheet impact of the pandemic.

\section{Hypotheses on COVID-19 disclosures as subsequent events}

Institutional theory claims that organizations, as a response to different pressures and expectations from their environment, adopt formal structures that are accepted and considered legitimate (Meyer and Rowan, 1977; DiMaggio and Powell, 1983). As such, institutional theory has proven to be relevant for identifying factors that influence financial reporting practices in various public sector contexts (e.g. Carpenter and Feroz, 2001; Oulasvirta, 2014; Argento et al., 2018; Donatella, 2020; Jorge et al., 2021).

DiMaggio and Powell (1983) sort institutional pressure and expectations into coercive, normative and mimetic isomorphism, and state that these forces eventually lead to conformity within organizational fields (e.g. within a sector). However, there are often competing institutional pressures and expectations (Oulasvirta, 2014; Polzer et al., 2021), and organizations do not always comply; furthermore, institutional change toward conformity might take time (Oliver, 1991). Since the COVID-19 pandemic was a swift and unfamiliar development with little time for discussion and reflection within the municipal sector, it is unclear - solely on institutional theoretical grounds - what effect these institutional forces had on the reporting of COVID-19 as a subsequent event. As suggested by Wolling (2016) and Frandsen and Johansen (2009), crises such as the COVID-19 crisis are characterized by a high level of uncertainty that changes in character over time. 


\subsection{Responses to a high level of uncertainty}

Within institutional theory, uncertainty is referred to as the degree to which future development cannot be accurately predicted (Oliver, 1991). This type of uncertainty is normally related to more constant uncertainties stemming from the unpredictability of the actions of regulators, citizens and suppliers, as well as economic and technological development (Allegrini and Monteduro, 2018; Gosh and Olsen, 2009). Oliver (1991) argues that, under a high level of uncertainty, conformity to institutional pressure and expectations is more likely to occur. Following this main argument, a high level of uncertainty should stimulate a willingness to comply to accounting regulations and to be transparent about the development and consequences of COVID-19. This is also the conventional wisdom: namely, that municipalities facing a high level of uncertainty are more likely to process and disclose information (Allegrini and Monteduro, 2018). A further argument in favor of such reporting is that stakeholders' demand for information increases during a crisis (Lee and Boynton, 2017) and municipalities tend to respond to stakeholder pressure by disclosing information in order to gain legitimacy (Carpenter and Feroz, 2001; Rodríguez Bolívar et al., 2013).

However, a high level of uncertainty does not always stimulate compliance, transparency and conformity. Oliver (1991) argues that, when the potential gain in legitimacy is perceived as low and when the coercive pressure is weak, organizations might instead respond with avoidance. It is common for public sector organizations to adopt a "silence" crisis response strategy, hoping that the crisis will just "go away" (Kim, 2016). Moreover, it is expected that coercive pressure to comply with municipal accounting regulations has probably not been a major influence on the willingness to report on COVID-19 as a subsequent event. In general, compliance with municipal accounting regulations in Sweden has been rather weak in the past (Falkman and Tagesson, 2008; Donatella, 2020); more specifically, as described in the introduction, no professional organizations in Sweden actively advocated for the pandemic to be treated as a subsequent event in the municipal annual reports of 2019.

Institutionalized accounting traditions present another important aspect in relation to uncertainty (Oulasvirta, 2014). The Swedish municipal accounting environment is characterized by conservatism and the disclosure of accountability-relevant information (Tagesson and Grossi, 2015). In such an environment, historical information with a high level of verification is preferred over timely, less verifiable future-oriented information (e.g. Oulasvirta, 2021). This tendency might be enhanced when the level of uncertainty is high.

Accounting professionals may have been a potent force when the annual reports of 2019 were prepared. These professionals are considered to be important institutional actors, since they are the experts and have the means and motivation to influence what constitute accepted practices (e.g. Mezias, 1990; Carpenter and Feroz, 2001; Gomes et al., 2015). In times of high uncertainty, a typical response is to mimic other organizations in order to reduce uncertainty (DiMaggio and Powell, 1983; Oliver, 1991); this implies that municipal accountants seek guidance in their professional networks (Donatella, 2020). Auditors also play a potentially important role in reducing uncertainty. From the perspective of institutional theory, auditors are associated with their normative influence (Falkman and Tagesson, 2008) and, as external experts, they may provide professional guidance regarding unclear accounting issues and thereby reduce uncertainty. Most likely, the issue of COVID-19 was discussed both in the auditor-client negotiation process of the 2019 annual report and in professional accounting networks. This is a potential basis for a common practice to emerge, even during such a short period as the spring of 2020.

Thus, to summarize, depending on the situation, uncertainty is a condition that may be a stimulator of financial accounting disclosure or a condition leading to reluctance to disclose information. Merging institutional theory, crisis information and transparency research, it can be argued that the scope and characteristics of the disclosed information could differ significantly, depending on the situational factors of the COVID-19 crisis (e.g. Lee and Boynton, 2017). This argument is based on two main reasons. First, from a crisis event 
perspective, the type of uncertainty changes over time. In the early stage, that is, the pre-crisis stage, the high level of uncertainty is related to the occurrence of the crisis; upon entering the event stage, this uncertainty is replaced by uncertainty about the consequences of the crisis (Wolling, 2016). From this perspective, reporting time is important, since the crisis may be in a different stage when the municipality finalizes the annual report. Second, the development of the COVID-19 pandemic did not evolve equally at the municipal level in Sweden; rather, municipalities were affected very differently by the pandemic at the reporting time, depending on the local spread of the disease and the preconditions of the municipality. This difference influences the verifiability and calculability of the consequences of the crisis. Here, we suggest that these two aspects - the crisis stage and how the municipality was affected by the pandemic - influenced municipalities' reporting practice. Following Hsieh et al. (2019), it is important to distinguish between uncertainty with known probabilities of outcomes (i.e. risk), and uncertainty for which such probabilities are unknown (i.e. ambiguity). These scholars argue that, when the uncertainty is not calculable, reporting entities will favor caution in valuation (i.e. accounting conservatism). This perspective may imply that municipalities under a conservative accounting regime are cautious to disclose information if it is difficult to assess the associated risks and when there is a lack of verifiable data. Following the general argument that the situational factors of crises influence organizational crisis information (e.g. Lee and Boynton, 2017), we suggest in this paper that the situational factors of the COVID-19 crisis are expected to have explanatory power, since they affect the type and level of uncertainty at the time of reporting. Against this background, we explore whether reporting time, regional confirmed cases, demographic factors (i.e. proportion of senior population), operational risk factors (i.e. proportion of seniors living in nursing homes) and financial risk factors (i.e. holding shares and securities) influence the likelihood of municipalities disclosing COVID-19 information as a subsequent event in the annual reports of 2019.

\subsection{Reporting time and the development of the COVID-19 pandemic}

Municipalities in Sweden do not issue their annual reports on the same date. The law only specifies that the municipal board must submit the annual report to the municipal council and the auditors "... as soon as possible, and no later than April 15 of the year following the year to which the report relates" (The Municipal Act, Chapter 11, Section 20 - the authors' translation). Although it is the municipal council that authorizes the annual report for issuance, the council has no power to change the content of the report. Therefore, if the municipal council decides not to approve the annual report for some reason, the municipal board will have to resubmit a revised version of the annual report. As a result, the crucial date for a subsequent event is when the municipal board submits the annual report to the municipal council.

In the early stage of the development of the pandemic, Sweden opted for a continuation of its "normal governance" approach (Kuhlmann et al., 2021). The debate in Sweden focused on whether the healthcare system had sufficient capacity to meet the anticipated increase in COVID-19 patients in need of emergency care. As the death toll rose, the focus of the debate shifted to how the spread of COVID-19 could be limited in society and, more specifically, prevented from spreading within the senior care system (Granberg et al., 2021; Kuhlmann et al., 2021). Eventually, this resulted in restrictions being imposed on local transportation, schools, sports, the cultural arena and so forth. Hence, the crisis materialized over time by gradually transitioning from a pre-crisis stage to a crisis stage. This transition is consistent with the notion that the uncertainty of the occurrence of a crisis generally decreases over time, even though the uncertainty regarding the impact may remain high (e.g. Wolling, 2016). Using a later submission date for the annual report therefore gives municipalities more validated information. Against this background, it is hypothesized that: 
H1. The likelihood of municipalities disclosing COVID-19 information as a subsequent event is positively related to the annual report submission date.

Although Sweden is a small country, different regions were affected by the COVID-19 pandemic very differently. Around the time of the legal deadline for the annual report submission, the municipalities in the area of Stockholm were severely affected, while other regions - even some densely populated ones - had relatively few confirmed cases and low death tolls. Thus, the COVID-19 crisis affected Swedish municipalities differently during the early stage of the crisis. This fact implies that the stages of the crisis were heterogeneously distributed across the country's municipalities. Theoretically, the number of confirmed cases by region has the potential to reduce the uncertainty of the occurrence of the crisis, since rising numbers verify the presence and severity of the pandemic crisis - which, in a conservative accounting environment, should stimulate disclosure. Furthermore, the local need and pressure for information should increase with a higher number of confirmed cases. Against this background, it is hypothesized that:

H2. The likelihood of municipalities disclosing COVID-19 information as a subsequent event is positively related to the number of confirmed COVID-19 cases at the regional level.

\subsection{Demographic, operational and financial risk factors}

The reporting of subsequent events is used to identify relevant events and risks that have occurred after the balance sheet date. Like crises in general (e.g. Rodríguez Bolívar et al., 2016), the COVID-19 pandemic implied different degrees of impact and risk for different municipalities in the early stages of the crisis. This heterogeneity of impact and risk can partly be attributed to important risk factors. Even though the consequences may have been very uncertain and difficult to calculate, tangible impacts and risk factors might have made the COVID-19 pandemic less ambiguous. Therefore, tangible impacts and risks might stimulate the inclusion of COVID-19 disclosures in the annual report. The pressure for action and information in municipalities with substantial risk factors might also be higher.

It was identified early on that age increased individuals' risk of severe consequences from COVID-19. Protecting senior citizens was thus an important part of the strategy of the Public Health Agency of Sweden (Kuhlmann et al., 2021). Against this background, it is hypothesized that:

H3. The likelihood of municipalities disclosing COVID-19 information as a subsequent event is positively related to the proportion of senior population.

On the same theme, but more closely related to municipal operation and services, a high proportion of those who were seriously infected or died with COVID-19 in the early stage of the pandemic in Sweden lived in municipal housing for seniors (Kuhlmann et al., 2021). The measure of closing homes for seniors to visits was taken relatively early. Against this background, it is hypothesized that:

H4. The likelihood of municipalities disclosing COVID-19 information as a subsequent event is positively related to the proportion of seniors living in nursing homes.

The COVID-19 pandemic has both short-term and long-term financial consequences. The first and most visible consequence of the COVID-19 pandemic was a significant drop on the financial stock markets. Some Swedish municipalities have invested large amounts in shares and securities. In Sweden, the crisis initially led to a strong stock market downturn. In February and March, the Stockholm Stock Exchange fell by 19\% (All Share Index), while a slight recovery took place in April. Thus, the decreased value of the shares and securities 
owned by the municipalities was a direct signal of the economic effect of the pandemic. It was also a calculable and verifiable subsequent event. This reduction of uncertainty suggests that municipalities having substantial holdings of shares and securities are more likely to have disclosed COVID-19 information, especially under a conservative accounting regime. Against this background, it is hypothesized that:

H5. The likelihood of municipalities disclosing COVID-19 information as a subsequent event is positively related to their holdings of shares and securities.

\section{Method and data}

As previously explained, the question of whether the COVID-19 outbreak should be regarded as a subsequent event under the current regulatory framework for municipal reporting in Sweden must essentially be determined by what was generally known around the time the municipal boards submitted their annual report to the municipal council. In Figure 1, the submission date for the 2019 annual reports is presented.

As shown in Figure 1, the annual reports for 2019 were submitted by municipal boards about a month or more after February 1, when COVID-19 was classified as a danger to society by the Swedish central government. With the exception of 33 municipalities, all municipal boards even submitted their annual report after the WHO's statement on March 11. This observation shows that information on the potential severity of the COVID-19 pandemic was available after the balance sheet date but before the submission of the annual report. Therefore, the COVID-19 outbreak certainly meets the abovementioned conditions regarding what qualifies as a subsequent event.

In the presented analysis of COVID-19 disclosures, we use cross-sectional data from 289 Swedish municipalities for 2019. Only one observation was excluded - that of Region Gotland - because Gotland is a hybrid between a municipality and a region, and is therefore not comparable to the other municipalities in terms of several of the independent variables included in the analysis. Additional analyses were made based on a subsample that excluded the 33 municipalities that submitted their annual report before the WHO statement.

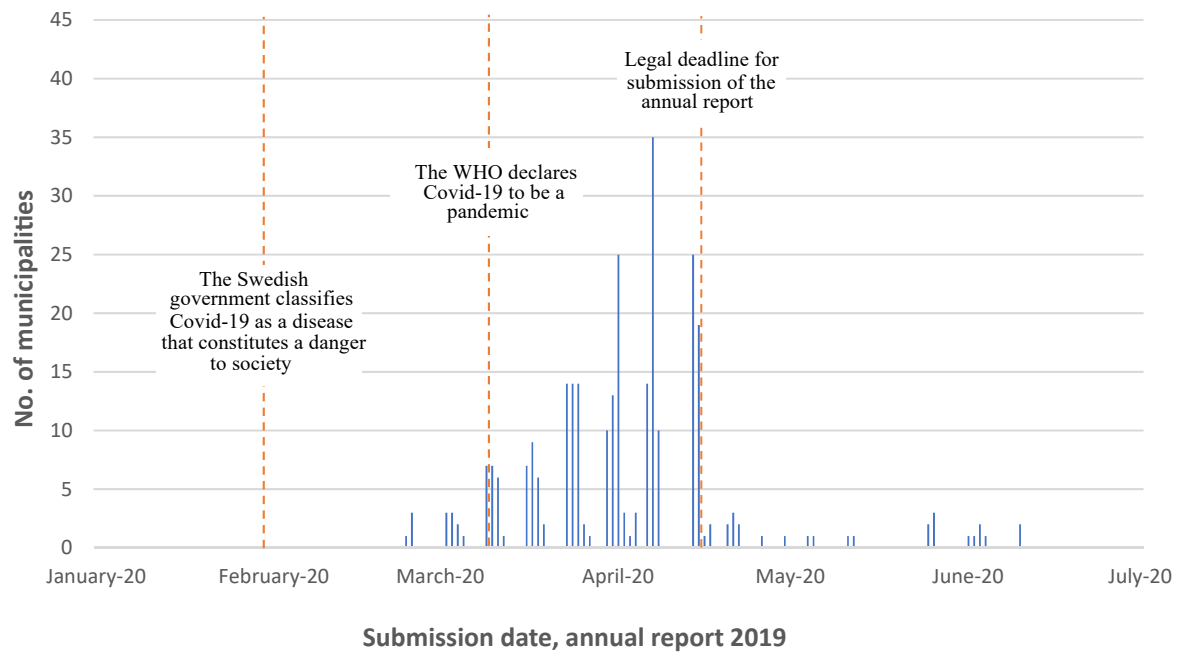

Source(s): Meeting minutes or personal contact
Reporting on COVID-19 - or not? 
After manually reviewing the annual reports for 2019, we concluded that there is a fairly substantial dichotomous variation in COVID-19 disclosures: in $56.4 \%$ of the cases, no COVID-19-related information was included in the annual report, whereas in $43.6 \%$ of the cases, such information was included. This variation directed us toward using an indicator variable when analyzing COVID-19 disclosure. However, some municipalities merely mentioned that COVID-19 might have an impact, rather than going into detail on matters such as the financial and operational risks associated with the pandemic [1]. Therefore, the independent variable namely, COVID-19 disclosures as a subsequent event (COVID19_DSE) - was coded as "0" if a municipality did not disclose any COVID-19 information or was among the bottom $5 \%$ in the group, in terms of the number of words used by municipalities in disclosing COVID-19 information; otherwise, the independent variable was coded as "1". Under this definition, municipalities that provided just one or two sentences on COVID-19 were not considered to have provided COVID-19 information substantial enough to be classified as having disclosed COVID-19 as a subsequent event. Alternative operationalizations of the dependent variable were used in an additional analysis, to test the robustness of the reported results.

\subsection{Independent variables}

The date at which the municipal board submitted the 2019 annual report (DAYS) was measured by calculating the number of days between the day of submission and January 1 , 2020. As previously noted, the municipal boards in several municipalities submitted their annual report to the municipal council and the auditors after the legal deadline had expired. To avoid outliers, and because small time differences are likely to have a greater impact in the beginning than at the end of the period, we used the natural logarithm of the number of days.

During the pandemic, the Public Health Agency of Sweden reported information on confirmed COVID-19 cases on a weekly basis. Considering the reporting lag, and given that a draft of the annual report had to be distributed prior to the municipal board meeting, we used the cumulative number of COVID-19 cases per 100,000 people at the regional level (REGIONAL_CASES) 2 weeks prior to the municipal board's submission of the annual report. Again, we used the logarithm of the variable in order to avoid problems with outliers. As some observations had a value of zero, we used the natural logarithm of REGIONAL_CASES +1 .

The operational risks associated with COVID-19 were measured using the relative number of members of the municipal population that are 70 years or older (POPULATION $\geq 70$ ) and the relative number of members of the municipal population 80 years or older who live in a nursing home (NURSING_HOME) (data source: Statistics Sweden). The financial risk was related to whether the municipalities held shares and securities. In order to reflect the inter-differences in the group of municipalities with such financial assets, we used an approach with three indicator variables. Municipalities holding shares and securities (about 31.5\% of all observations) were coded based on the size of these financial assets: the bottom half of municipalities in terms of shares and securities per resident (SHARES_SECURITIES_BOTTOM) was coded as "1", and all other municipalities were coded as " 0 ", and the top half of municipalities in terms of shares and securities per resident (SHARES_SECURITIES_TOP) was coded as "1", and all other municipalities were coded as " 0 ". Municipalities holding no shares and securities (NO_SHARES_SECURITIES) were coded as "1", and those that were holding shares and securities were coded as " 0 ", and were used as the reference category in the regression analysis.

\subsection{Control variables}

The common factors in public sector disclosure research are political competition, financial conditions, intergovernmental subsidies, municipal size and population wealth (Rodríguez 
Bolívar et al., 2013; Alcaide Muñoz and Rodríguez Bolívar, 2015). In order to be consistent with prior research, we included several control variables in our analysis.

We used the number of changes in government during the last three elections (GOVERNMENT_CHANGE) to measure political competition. We also included two indicator variables that measure the strength of the political opposition more directly. Municipalities that were governed by a coalition of one or more right-wing and left-wing parties were coded as " 1 ", and those that were not were coded as "0" (BROAD_COALITION), while municipalities in which the governing party or parties controlled less than $50 \%$ of the seats in the municipal council were coded as " 1 ", and those that were not were coded as " 0 " (MINORITY_GOVERNMENT). Data for these variables were retrieved from SALAR and Statistics Sweden.

Municipal size, financial conditions and intergovernmental subsidies were also included as control variables. Municipal size was measured by the natural logarithm of population (POPULATION_SIZE). Financial conditions were measured by the equity ratio including all pension obligations (EQUITY) and dependence on intergovernmental subsidies was measured by scaling the government grants a municipality received with its own tax revenues $(G R A N T)$. The wealth of citizens was excluded in order to avoid multicollinearity problems. In Sweden, there is an equalization system that allocates and reallocates resources to municipalities based on the municipality tax base (i.e. the average income of residents) and on factors that drive the cost of services (Tagesson and Grossi, 2015). Therefore, government grants strongly correlate with the wealth of the population in the municipality. Data for these variables were retrieved from Statistics Sweden.

In addition to the common factors discussed above, we added controls for audit firms and regions. Previous research in the context of Swedish municipalities indicates that levels of compliance with regulatory requirements vary depending on the engaged audit firm (e.g. Haraldsson and Tagesson, 2014; Donatella, 2021). However, a specific institutional condition must be mentioned in regard to municipal auditing in Sweden: professional auditors from audit firms do not sign or express any audit opinion in the formal audit report. Instead, the audit report is written and signed by the politically appointed auditors. Although the professional auditors only assist the politically appointed auditors in their work, the audit report by the politically appointed auditors relies heavily on the work of the professional auditors (Tagesson and Eriksson, 2011). Therefore, it is required by law that a report from professional auditors must be attached to the formal audit report (The Municipal Act, Chapter 12, Section 8). Another institutional condition is that the "Big 4" audit firms hold almost the entire municipal audit market, and that $\mathrm{PwC}$ is considered to be the industry specialist after the acquisition of KOMREV (an audit firm that specialized in municipal auditing) from the predecessor of SALAR in 1996 (Tagesson et al., 2015). This acquisition gave $\mathrm{PwC}$ a large market share and employees with extensive municipal experience. $\mathrm{PwC}$ has retained its position as the industry specialist (Collin et al., 2017; Donatella, 2021), but has more recently faced a loss in market share. Considering these conditions, an indicator variable was used for each of the Big 4 audit firms (DELOITTE, $E Y, K P M G$, and $P w C$ ); a separate indicator variable was used for municipalities that were audited by an internal audit office or a non-Big 4 audit firm (AUDIT_RESIDUAL). All the audit variables were coded as " 1 " if yes, and as "0" otherwise. Due to its status as the industry specialist, $\mathrm{PwC}$ was used as the reference category in the regression analysis. Data were hand collected from the audit reports.

Accounting choices in Swedish municipalities tend to converge at the regional level, due to voluntary networks in which accounting departments from neighboring municipalities meet and share experiences on a regular basis (Donatella, 2020; Donatella and Tagesson, 2021). The administrative division of the country into regions was therefore used to control for geographical differences in COVID-19 disclosures. An indicator variable, coded as "1" if yes, 
and as "0" otherwise, was used for each region. Municipalities in Region Jönköping were used as the reference category in the regression analysis, as this region had the first confirmed case of COVID-19 in Sweden.

\section{Results}

Descriptive statistics for all variables are presented in Table 1. According to the definition used, well under half of the municipalities disclosed COVID-19 information as a subsequent event in the 2019 annual report. On average, municipal boards submitted their annual report about 92 days $(\log =4.504)$ after January 1, 2020. The confirmed cumulative COVID-19 cases per 100,000 people, 2 weeks prior to the annual report submission, were about $29(\log =2.592)$ at the regional level. On average, $17.6 \%$ of the municipal population is 70 years or older, and $11.5 \%$ of the population is 80 years or older and lives in nursing homes. Most municipalities $(68.2 \%)$ hold no shares or securities.

The bivariate results reported in Table 2 indicate that the independent variable holds the expected correlation with the COVID19_DSE variable. However, only DAYS and REGIONAL_CASES are significant and strongly correlated with COVID19_DSE (Spearman's rho $>0.3$, sig. 2-tailed $<0.001$ ). Additional bivariate analysis (not tabulated) shows that the variables DAYS and REGIONAL_CASES are strongly correlated with each other (Spearman's rho $>0.9$ ), so they are not included in the same model. Other bivariate correlations between the independent/control variables are much lower, indicating that there is no cause for concern regarding multicollinearity if they are included in the same model.

\begin{tabular}{|c|c|c|c|c|}
\hline Variable & Mean & Std. dev. & Min. & Max. \\
\hline COVID19_DSE & 0.415 & 0.494 & 0 (no) & 1 (yes) \\
\hline DAYS & 4.504 & 0.186 & 3.97 & 5.07 \\
\hline REGIONAL_CASES & 2.592 & 1.458 & $<0.01$ & 5.70 \\
\hline POPULATION70 & 0.176 & 0.033 & 0.09 & 0.27 \\
\hline NURSING_HOME & 0.115 & 0.027 & 0.01 & 0.24 \\
\hline SHARES_SEECURITIES_TOP & 0.159 & 0.366 & 0 (no) & 1 (yes) \\
\hline SHARES_SECURITIES_BOTTOM & 0.156 & 0.363 & 0 (no) & 1 (yes) \\
\hline NO_SHARES_SECURITIES & 0.682 & 0.467 & 0 (no) & 1 (yes) \\
\hline GOVERNMENT_CHANGE & 0.889 & 0.902 & 0.00 & 3.00 \\
\hline BROAD_COALITTION & 0.395 & 0.490 & 0 (no) & 1 (yes) \\
\hline MINORITY_GOVERNMENT & 0.398 & 0.490 & 0 (no) & 1 (yes) \\
\hline POPULATION_SIZE & 869 & 33 & 7.79 & 13.79 \\
\hline EQUITY & 0.192 & 0.190 & -0.45 & 0.72 \\
\hline GRANT & 0.236 & 0.103 & -0.29 & 0.45 \\
\hline DELOITTE & 0.031 & 0.174 & 0 (no) & 1 (yes) \\
\hline EY & 0.187 & 0.390 & 0 (no) & 1 (yes) \\
\hline KPMG & 0.320 & 0.468 & 0 (no) & 1 (yes) \\
\hline $\mathrm{PwC}$ & 0415 & 0494 & 0 (no) & 1 (yes) \\
\hline AUDIT_RESIDUAL & 0.045 & 0.208 & 0 (no) & 1 (yes) \\
\hline \multicolumn{5}{|c|}{ 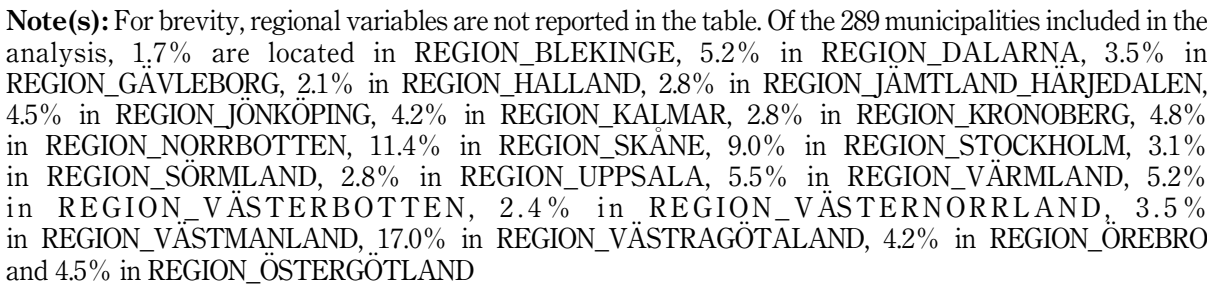 } \\
\hline
\end{tabular}

Table 1.

Descriptive statistics 


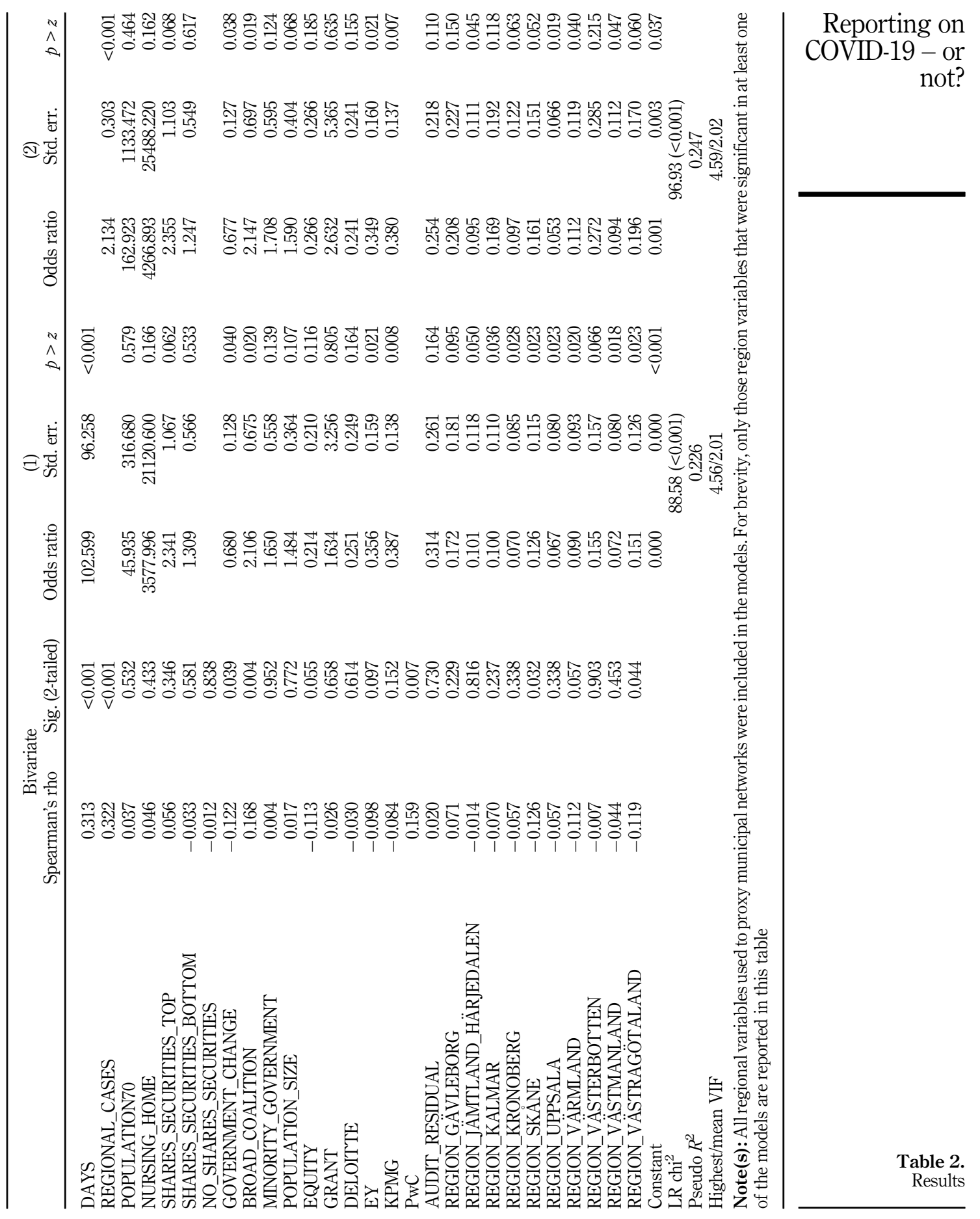


To avoid multicollinearity problems, the results are presented using two different logistic regression models. The effects of the independent and control variables on COVID19_DSE are estimated as follows:

$$
\begin{aligned}
\text { COVID19_DSE }= & \beta 0+\beta_{1} \text { DAYS }_{i}+\beta_{2} \text { POPULATION70 }_{2} \beta_{3} \text { NURSING_HOME }_{i} \\
& +\beta_{4} \text { SHARES_SECURITIES_TOP }_{i} \\
& +\beta_{5} \text { SHARES_SECURITIES_BOTTOM }_{i} \\
& +\beta_{6} \text { GOVERNMENT_CHANGE }_{i}+\beta_{7} \text { BROAD_COALITION }_{i} \\
& +\beta_{8} \text { MINORITY_GOVERNMENT }_{i}+\beta_{9} \text { POPULATION_SIZE }_{i} \\
& +\beta_{10} \text { EQUITY }_{i}+\beta_{11} \text { GRANT }_{i}+\beta_{12} \text { DELOITTE }_{i}+\beta_{13} \text { EY }_{i} \\
& +\beta_{14} \text { KPMG }_{i}+\beta_{15} \text { AUDIT_RESIDUAL }_{i} \\
& +\beta_{16} \text { REGION_BLEKINGE }_{i}+\beta_{17} \text { REGION_DALARNA }_{i} \\
& +\beta_{18} \text { REGION_GÄVLEBORG }_{i} \\
& +\beta_{19} \text { REGION_HALLAND }_{i} \\
& +\beta_{20} \text { REGION_JÄMTLAND_HÄRJEDALEN }_{i} \\
& +\beta_{21} \text { REGION_KALMAR }_{i}+\beta_{22} \text { REGION_KRONOBERG }_{i} \\
& +\beta_{23} \text { REGION_NORRBOTTEN }_{i}+\beta_{24} \text { REGION_SKÅNE }_{i} \\
& +\beta_{25} \text { REGION_STOCKHOLM }_{i}+\beta_{26} \text { REGION_SÖRMLAND }_{i} \\
& +\beta_{27} \text { REGION_UPPSALA }_{i}+\beta_{28} \text { REGION_VÄRMLAND }_{i} \\
& +\beta_{29} \text { REGION_VÄSTERBOTTEN }_{i} \\
& +\beta_{30} \text { REGION_VÄSTERNORRLAND }_{i} \\
& +\beta_{31} \text { REGION_VÄSTMANLAND }_{i} \\
& +\beta_{32} \text { REGION_VÄSTRAGÖTALAND }_{i} \\
& +\beta_{33} \text { REGION_ÖREBRO }_{i} \\
& +\beta_{34} \text { REGION_ÖSTERGÖTLAND }_{i}+\varepsilon_{i} \\
&
\end{aligned}
$$

The same specification is used in Model 2, except for $\beta_{1}$; instead of DAYS, the variable REGIONAL_CASES is included.

The regression results are presented in Table 2. Both models are significant $(\phi<0.001)$, and their explanatory power varies from a pseudo $R^{2}$ value of $22.6 \%$ in Model 1 (where the DAYS variable is used) to $24.7 \%$ in Model 2 (where the REGIONAL_CASES variable is used).

DAYS (in Model 1) and REGIONAL_CASES (in Model 2) are both highly significant $(p<0.001)$. When other factors are held constant, the results indicate that municipalities with late submission dates of their annual report and higher numbers of confirmed COVID19 cases at the time of the annual report submission were more likely to disclose information on COVID-19 as a subsequent event, thus supporting $\mathrm{H} 1$ and $\mathrm{H} 2$. As indicated by the different pseudo $R^{2}$ values produced by the two models, REGIONAL_CASES carries the greatest predictive accuracy in terms of estimating COVID-19 disclosure. However, DAYS also carries substantial explanatory power. If included as the only explanatory variable in a model, DAYS and REGIONAL_CASES produce pseudo $R^{2}$ values of 6.7 and 
$8.4 \%$, respectively, which correspond to approximately one-third of the explanatory power of the full models.

SHARES_SECURITIES_TOP is moderately significant in both models. When other factors are held constant, the results indicate that municipalities with relatively large values in shares and securities were more likely to disclose information on COVID-19 than municipalities without such financial assets. However, SHARES_SECURITIES_BOTTOM does not significantly differ from NO_SHARES_SECURITIES. This indicates that it is when substantial financial assets are at risk that municipalities disclose information. Thus, the results partially support $\mathrm{H} 5$.

When other factors were held constant, neither POPULATION70 nor NURSING_HOME was significant. This finding indicates that the risk of COVID-19 due to the municipalities' demographic and operational conditions was not a major factor. $\mathrm{H} 3$ and $\mathrm{H} 4$ must therefore be rejected.

Several of the control variables were significantly related to the likelihood of COVID19_DSE. However, starting with the factors commonly used in the disclosure literature, neither EQUITY or GRANT were significantly related to COVID19_DSE. Moreover, there are results - albeit only moderately significant ones - that indicate that SIZE had a positive impact on the likelihood of COVID19_DSE. It is difficult to draw any definite conclusions based on this correlation, considering that prior disclosure research has shown very mixed empirical results regarding the impact of size, even under normal conditions and circumstances (Christiaens, 1999; Rodríguez Bolívar et al., 2013; Alcaide Muñoz and Rodríguez Bolívar, 2015). In both models, GOVERNMENT_CHANGE significantly decreased the likelihood of COVID19_DSE, whereas BROAD_COALITION significantly increased its likelihood. Contrary to what is expected and typically found under normal conditions and circumstances (e.g. Rodríguez Bolívar et al., 2013; Alcaide Muñoz and Rodríguez Bolívar, 2015), these results indicate that political competition had a negative impact on disclosure in the context of the COVID-19 crisis.

In line with prior empirical research in the context of Swedish municipalities, we found differences across audit firms and regions. Compared with the municipalities audited by $\mathrm{PwC}$, the industry specialist audit firm, municipalities audited by EY or KPMG had a significantly decreased likelihood of COVID19_DSE. These findings corroborate the results reported by Donatella (2021), which suggest that municipalities audited by $\mathrm{PwC}$ tend to disclose more mandatory information. We interpret this result as an indication that $\mathrm{PwC}$ differentiates itself from other audit firms in terms of its ability to normatively influence compliance with regulatory requirements (cf. Falkman and Tagesson, 2008). The observed regional differences in COVID19_DSE are consistent with the idea that reporting practices converge at the regional level due to interactions between neighboring municipalities (Donatella, 2020; Donatella and Tagesson, 2021). Although these results are fairly stable, it must be considered that the regional variables in Model 1 are likely to capture regional differences in the severity of the pandemic. In Model 2, the regional differences are captured by the REGIONAL_CASES variable. Therefore, coefficient estimates for the regional variables vary slightly between the two models.

Additional analysis (not tabulated) showed that the above-reported results are robust to alternative operationalizations of the dependent variable, and are similarly robust when analyses are based on a subsample that includes only the 256 observations in which the municipal board submitted the annual report to the municipal council and the auditors after the date on which the WHO declared COVID-19 to be a pandemic. The models' explanatory power increases (decreases) slightly when using a higher (lower) threshold for whether COVID-19 was disclosed as a subsequent event. A higher (lower) threshold is obtained by coding the dependent variable as " 0 " if a municipality did not disclose any COVID-19 information or was among the bottom $10 \%$ in the number of words used to disclose COVID-19 information among 
the group of disclosing municipalities, while those that did disclose COVID-19 and were not among the bottom $10 \%$ were coded as "1" " 0 " if a municipality did not disclose any COVID-19 information, and "1" if they did). Except forSHARES_SECURITIES_TOP, the results related to the test of the hypotheses remain qualitatively unchanged. When using the higher threshold for the dependent variable, SHARES_SECURITIES_TOP is not significant. However, when using the lower threshold, the correlation is still significant, albeit at the $5 \%$ level. Similarly, in the subsample analysis $(n=256)$,SHARES_SECURITIES_TOP differs in comparison with the full sample analysis, as it is not significant. Again, the results related to other hypotheses were qualitatively unchanged.

\section{Conclusions}

"Are you afraid of the thunder?" Pelle asks Tjorven in the classic story of Sea Crow Island by Astrid Lindgren (1964/2016, p. 131). "No', she said, 'not really - only sometimes - only when it's thundering"'.

Like Tjorven, who is only afraid of the thunder when it is thundering, local politicians seem to have been unconcerned over COVID-19 in the pre-crisis stage in Sweden. Municipalities that issued their annual report in a later stage of the pandemic, when COVID-19 was already widespread in society and the death toll had increased, were more likely to disclose COVID-19 information as a subsequent event in their annual report than municipalities that issued their annual report at an earlier stage of the pandemic. In contrast, the situational factors used to capture the risk of a severe impact of the COVID-19 outbreak were found not to be of major importance. These findings align with a critique from Granberg et al. (2021), who state that Swedish municipalities were initially unprepared and ill-equipped to deal with the situation.

The fact that less than half of the municipalities disclosed COVID-19 information as a subsequent event in the 2019 annual reports suggests that the municipal sector mainly employed what Oliver (1991) describes as an avoidance strategy. Our study indicates that evidence in the form of very concrete, substantial and verifiable consequences, which decreases the level of uncertainty, is required before a subsequent event is reported. This practice of requiring strict verifiability is in line with the tradition of historical cost accounting, which emphasizes the control of budgets as a basis for ex post accountability, rather than aligning with the more future-oriented ex ante accounting, which is the decisionusefulness approach. Although there are strong arguments for an accountability-based approach in public sector accounting (Ellwood and Newberry, 2016; Mann et al., 2019; Oulasvirta, 2021), disclosures that relate to future periods should not be ruled out as a complement to financial statements in order to deal with the trade-off between accountability and decision-usefulness.

Finally, our study shows that both political and institutional-related arguments have explanatory power that can help to predict and explain accounting disclosure choices in times of crisis. According to Rodríguez Bolívar et al. (2013), empirical studies present somewhat mixed results for the variable of political competition. Nevertheless, the meta-analytic study by these scholars supports a generally positive association between political competition and accounting disclosure measures. Our study, on the other hand, shows that political competition in the early stage of a crisis have a negative effect on disclosure practice - at least in regard to the reporting of COVID-19 information as a subsequent event. These different research findings indicate that the level of uncertainty may moderate the relationship between political competition and accounting disclosure. However, this is a question for future research.

In addition, and in line with previous research, this study produced results suggesting that the ability to correctly predict and explain accounting disclosure choices by public sector 
organizations increases when institutional factors - especially normative and mimetic forces - are included in the explanatory model. This finding is consistent with the argument that a typical response in times of uncertainty is to rely on professional guidance from auditors and members of accounting networks. If these institutional forces do not act in a uniform manner (e.g. if there are differences between different audit firms and auditors), it will lead to differences in disclosure practices between the organizations that are subject to reporting regulations. Thus, in highly uncertain periods, such as in the early stage of a crisis, it is critical that institutional actors (e.g. standard setters and auditors) act clearly and consistently. Otherwise, different approaches to disclosure about events will result and, as this study indicates, will probably be characterized by widespread non-disclosure behavior.

\section{Note}

1. Descriptive statistics for the number of COVID-19-related words $(n=126)$ : min value $=13$; first quartile $=61$; median $($ second quartile) $=112$; third quartile $=203$; max value $=1,246$; and mean $=167$.

\section{References}

Ahrens, T. and Ferry, L. (2020), "Financial resilience of English local government in the aftermath of COVID-19", Journal of Public Budgeting, Accounting and Financial Management, Vol. 32 No. 5, pp. 813-823, doi: 10.1108/JPBAFM-07-2020-0098.

Alcaide Muñoz, L. and Rodríguez Bolívar, M.P. (2015), "Determining factors of transparency and accountability in local governments: a meta-analytic study", Lex Localis, Vol. 13 No. 2, pp. 129-160, doi: 10.4335/13.2.129-160(2015).

Allegrini, V. and Monteduro, F. (2018), "The role of uncertainty in performance information disclosure", International Journal of Public Sector Management, Vol. 31 No. 5, pp. 583-598, doi: 10.1108/IJPSM-08-2017-0216.

Argento, D., Kaarbøe, K. and Vakkuri, J. (2020), "Constructing certainty through public budgeting: budgetary responses to the COVID-19 pandemic in Finland, Norway and Sweden", Journal of Public Budgeting, Accounting and Financial Management, Vol. 32 No. 5, pp. 875-887, doi: 10. 1108/JPBAFM-07-2020-0093.

Argento, D., Peda, P. and Grossi, G. (2018), "The enabling role of institutional entrepreneurs in the adoption of IPSAS within a transitional economy: the case of Estonia", Public Administration and Development, Vol. 38 No. 1, pp. 39-49, doi: 10.1002/pad.1819.

Avery, E.J., Graham, M. and Park, S. (2016), "Planning makes (closer to) perfect: exploring United States' local government officials' evaluations of crisis management”, Journal of Contingencies and Crisis Management, Vol. 24 No. 2, pp. 73-81, doi: 10.1111/1468-5973.12109.

Barbera, C., Jones, M., Korac, S., Saliterer, I. and Steccolini, I. (2017), “Governmental financial resilience under austerity in Austria, England and Italy: how do local governments cope with financial shocks?", Public Administration, Vol. 95 No. 3, pp. 670-697, doi: 10.1111/padm.12350.

Bisogno, M., Citro, F., Santis, S. and Tommasetti, A. (2017), "Disclosure quality measurement in the public sector: a structured literature review", International Journal of Business and Management, Vol. 12 No. 12, pp. 119-134, doi: 10.5539/ijbm.v12n12p119.

Bouckaert, G., van Hecke, S., Galli, D., Kuhlmann, S. and Reiter, R. (2020), "European coronationalism? A hot spot governing a pandemic crisis", Public Administration Review, Vol. 80 No. 5, pp. 765-773, doi: 10.1111/puar.13242.

Carpenter, V.L. and Feroz, E.H. (2001), "Institutional theory and accounting rule choice: an analysis of four US state governments' decisions to adopt generally accepted accounting principles", Accounting, Organizations and Society, Vol. 26 Nos 7-8, pp. 565-596, doi: 10.1016/S0361-3682(00) 00038-6. 
Christiaens, J. (1999), "Financial accounting reform in Flemish municipalities: an empirical investigation”, Financial Accountability and Management, Vol. 15 No. 1, pp. 21-40, doi: 10. 1111/1468-0408.00072.

Collin, S.O., Haraldsson, M., Tagesson, T. and Blank, V. (2017), "Explaining municipal audit costs in Sweden: reconsidering the political environment, the municipal organisation and the audit market”, Financial Accountability and Management, Vol. 33 No. 4, pp. 391-405, doi: 10.1111/ faam.12130.

Czerney, K., Schmidt, J.J., Thompson, A.M. and Zhu, W. (2020), "Do type II subsequent events impair financial reporting quality?”, The Accounting Review, Vol. 95 No. 6, pp. 97-123, doi: 10.2308/ accr-52662.

DiMaggio, P. and Powell, W.W. (1983), "The iron cage revisited: collective rationality and institutional isomorphism in organizational fields", American Sociological Review, Vol. 48 No. 2, pp. 147-160, doi: $10.2307 / 2095101$.

Donatella, P. (2020), "Determinants of mandatory disclosure compliance in Swedish municipalities", Journal of Public Budgeting, Accounting and Financial Management, Vol. 32 No. 2, pp. 247-265, doi: 10.1108/JPBAFM-03-2019-0048.

Donatella, P. (2021), "Further evidence on the relationship between audit industry specialisation and public sector audit quality", Financial Accountability and Management, online first. doi: 10.1111/ faam.12278.

Donatella, P. and Tagesson, T. (2021), "CFO characteristics and opportunistic accounting choice in public sector organizations", Journal of Management and Governance, Vol. 25 No. 2, pp. 509-534, doi: 10.1007/s10997-020-09521-1.

Ellwood, S. and Newberry, S. (2016), "New development: the conceptual underpinnings of international public sector accounting", Public Money and Management, Vol. 36 No. 3, pp. 231-234, doi: 10. 1080/09540962.2016.1140974.

Falkman, P. and Tagesson, T. (2008), "Accrual accounting does not necessarily mean accrual accounting: factors that counteract compliance with accounting standards in Swedish municipal accounting", Scandinavian Journal of Management, Vol. 24 No. 3, pp. 271-283, doi: 10.1016/j.scaman.2008.02.004.

FAR (2020), "Upplysningar om händelser efter balansdagen på grund av coronautbrottet [Disclosure on events after the balance sheet date due to the corona outbreak]", available at: https://www. far.se/aktuellt/nyheter/2020/mars/upplysningar-om-handelser-efter-balansdagen-pa-grund-avcoronautbrottet/ (accessed 2 February 2021).

Frandsen, F. and Johansen, W. (2009), "Institutionalizing crisis communication in the public sector: an explorative study in Danish municipalities", International Journal of Strategic Communication, Vol. 3 No. 2, pp. 102-115, doi: 10.1080/15531180902805460.

Gomes, P.S., Fernandes, M.J. and Carvalho, J.B.D.C. (2015), "The international harmonization process of public sector accounting in Portugal: the perspective of different stakeholders", International Journal of Public Administration, Vol. 38 No. 4, pp. 268-281, doi: 10.1080/01900692.2015.1001237.

Gosh, D. and Olsen, L. (2009), "Environmental uncertainty and managers' use of discretionary accruals", Accounting, Organizations and Society, Vol. 34, pp. 188-205, doi: 10.1016/j.aos.2008. 07.001.

Granberg, M., Rönnblom, M., Padden, M., Tangnäs, J. and Öjehag, A. (2021), "Debate: covid-19 and Sweden's exceptionalism: a spotlight on the cracks in the social fabric of a mature welfare state", Public Money and Management, online first. doi: 10.1080/09540962.2020.1866842.

Haraldsson, M. and Tagesson, T. (2014), "Compromise and avoidance: the response to new legislation”, Journal of Accounting and Organizational Change, Vol. 10 No. 3, pp. 288-313, doi: 10.1108/JAOC-10-2012-0096.

Hsieh, C.C., Ma, Z. and Novoselov, K.E. (2019), "Accounting conservatism, business strategy, and ambiguity”, Accounting, Organizations and Society, Vol. 74, pp. 41-55, doi: 10.1016/j.aos.2018.08.001. 
Huang, Y.-H. and Su, S.-H. (2009), "Determinants of consistent, timely, and active responses in corporate crises", Public Relations Review, Vol. 35 No. 1, pp. 7-17, doi: 10.1016/j.pubrev.2008.09.020.

IFAC (2020), "The financial reporting implications of COVID-19", available at: https://www.ifac.org/ knowledge-gateway/supporting-international-standards/discussion/financial-reportingimplications-covid-19 (accessed 21 June 2021).

IPSASB (2020), "COVID-19: relevant IPSASB accounting guidance", available at: https://www.ifac.org/ system/files/publications/files/IPSASB-Staff-QA-COVID-19-Relevant-Accounting-Guidance_0. pdf (accessed 25 March 2021).

Jorge, S., Nogueira, S.P. and Ribeiro, N. (2021), "The institutionalization of public sector accounting reforms: the role of pilot entities", Journal of Public Budgeting, Accounting and Financial Management, Vol. 33 No. 2, pp. 114-137, doi: 10.1108/JPBAFM-08-2019-0125.

Kim, S. (2016), "Crisis communication research in South Korea", in Schwarz, A., Seeger, M.W. and Auer, C. (Eds), The Handbook of International Crisis Communication Research, Wiley-Blackwell, West Sussex, pp. 236-247. doi: 10.1002/9781118516812.ch22.

KPMG (2020), "Hantera effekter av covid-19 i årets rapporter [Dealing with the effects of covid-19 in this year's reports]", available at: https:/home.kpmg/se/sv/home/nyheter-rapporter/2020/03/ hantera-effekter-av-covid-19-i-arets-rapporter.html (accessed 2 February 2021).

Kuhlmann, S., Hellström, M., Ramberg, U. and Reiter, R. (2021), "Tracing divergence in crisis governance: responses to the COVID-19 pandemic in France, Germany and Sweden compared", International Review of Administrative Sciences, online first. doi: 10.1177/0020852320979359.

Lee, T.H. and Boynton, L.A. (2017), "Conceptualizing transparency: propositions for the integration of situational factors and stakeholders' perspectives", Public Relations Inquiry, Vol. 6 No. 3, pp. 233-251, doi: 10.1177/2046147X17694937.

Lindgren, A. (1964/2016), Seacrow Island, Oxford University Press, Oxford.

Mann, B., Lorson, P.C., Oulasvirta, L. and Haustein, E. (2019), "The quest for a primary EPSAS purpose - insights from literature and conceptual frameworks", Accounting in Europe, Vol. 16 No. 2, pp. 195-218, doi: 10.1080/17449480.2019.1632467.

Meyer, J.W. and Rowan, B. (1977), "Institutionalized organizations: formal structure as myth and ceremony", American Journal of Sociology, Vol. 83 No. 2, pp. 340-363, doi: 10.1086/226550.

Mezias, S.J. (1990), "An institutional model of organizational practice: financial reporting at the Fortune 200”, Administrative Science Quarterly, Vol. 35 No. 3, pp. 431-457, doi: 10.2307/2393312.

Michels, J. (2017), "Disclosure versus recognition: inferences from subsequent events", Journal of Accounting Research, Vol. 55 No. 1, pp. 3-34, doi: 10.1111/1475-679X.12128.

Oliver, C. (1991), "Strategic response to institutional processes", Academy of Management Review, Vol. 16 No. 1, pp. 145-179, doi: 10.5465/amr.1991.4279002.

Oulasvirta, L. (2014), "The reluctance of a developed country to choose international public sector accounting standards of the IFAC. A critical case study", Critical Perspectives on Accounting, Vol. 25 No. 3, pp. 272-285, doi: 10.1016/j.cpa.2012.12.001.

Oulasvirta, L. (2021), “A consistent bottom-up approach for deriving a conceptual framework for public sector financial accounting", Public Money and Management, online first. doi: 10.1080/ 09540962.2021.1881235.

Polzer, T., Grossi, G. and Reichard, C. (2021), "Implementation of the international public sector accounting standards in Europe. Variations on a global theme", Accounting Forum, pp. 1-26, online first. doi: 10.1080/01559982.2021.1920277.

Rodríguez Bolívar, M.P., Alcaide Muñoz, L. and López Hernández, A.M. (2013), "Determinants of financial transparency in government", International Public Management Journal, Vol. 16 No. 4, pp. 557-602, doi: 10.1080/10967494.2013.849169. 
Rodríguez Bolívar, M.P., Navarro Galera, A., Alcaide Muñoz, L. and López Subirés, M.D. (2016), "Risk factors and drivers of financial sustainability in local government: an empirical study", Local Government Studies, Vol. 42 No. 1, pp. 29-51, doi: 10.1080/03003930.2015.1061506.

Roux-Dufort, C. (2016), "Delving into the roots of crises: the genealogy of surprise", in Schwarz, A., Seeger, M.W. and Auer, C. (Eds), The Handbook of International Crisis Communication Research, Wiley-Blackwell, West Sussex, pp. 24-33, doi: 10.1002/9781118516812.ch3.

Singh, H. (2020), "Så upplyser du i årsredovisningen om covid-19:s ekonomiska konsekvenser [This is how you disclose COVID-19's financial consequences in the annual report]", available at: https:// blogg.pwc.se/foretagarbloggen/arsredovisning-covid-19 (accessed 2 February 2021).

Tagesson, T. and Eriksson, O. (2011), "What do auditors do? Obviously they do not scrutinise the accounting and reporting", Financial Accountability and Management, Vol. 27 No. 3, pp. 272-285, doi: 10.1111/j.1468-0408.2011.00525.x.

Tagesson, T., Glinatsi, N.A. and Prahl, M. (2015), "Procurement of audit services in the municipal sector: the impact of competition", Public Money and Management, Vol. 35 No. 4, pp. 273-280, doi: 10.1080/09540962.2015.1047270.

Tagesson, T. and Grossi, G. (2015), "Public sector accounting and auditing in Sweden", in Brusca, I., Caperchione, E., Cohen, S. and Manes Rossi, F. (Eds), Public Sector Accounting and Auditing in Europe: The Challenge of Harmonization, Palgrave Macmillan, Hampshire, pp. 189-203. doi: 10. 1057/9781137461346_13.

Tagesson, T., Klugman, M. and Lindvall, M. (2013), "What explains the extent and content of social disclosures in Swedish municipalities' annual reports", Journal of Management and Governance, Vol. 17 No. 2, pp. 217-235, doi: 10.1007/s10997-011-9174-5.

The Annual Accounts Act no. 1995:1554 [Årsredovisningslag (1995:1554)].

The Municipal Bookkeeping and Accounting Act no. 2018:597 [Lag (2018:597) om kommunal bokföring och redovisning].

The Municipal Act no. 2017:725 [Kommunallag (2017:725)].

Wolling, J. (2016), "Environmental crises and the public: media audiences in the context of environmental and natural threats and disasters", Schwarz, A., Seeger, M.W. and Auer, C. (Eds), The Handbook of International Crisis Communication Research, Wiley-Blackwell, West Sussex, pp. 236-247. doi: 10.1002/9781118516812.ch22.

\section{Corresponding author}

Pierre Donatella can be contacted at: pierre.donatella@spa.gu.se

For instructions on how to order reprints of this article, please visit our website:

www.emeraldgrouppublishing.com/licensing/reprints.htm

Or contact us for further details: permissions@emeraldinsight.com 